\title{
Climate Change and Adaptive Strategies in Brazil: the economic effects of genetic breeding ${ }^{1}$
}

\author{
Marcel Viana Pires ${ }^{2}$ and Dênis Antônio da Cunha ${ }^{3}$
}

\begin{abstract}
Plant breeding through the development of seeds resistant to water stress or high temperature is an important adaptive strategy to cope climate change. In this way, by providing an analysis of adaptation to climate change using genetic breeding on Brazilian farms, this work aims to investigate how climate change will affect the adoption of genetic breeding and profitability of farmers. Temperature and rainfall projections for 2010-2099 time periods were used, considering different climate scenarios (A1B and A2), according to the $4^{\text {th }}$ Assessment Report of IPCC (2007). A Treatment Effects model outlines the analytical framework in this study. Our results indicate the probability of adopting transgenic seeds will grow from $74 \%$ in the current period to $86 \%$ in $2020,83 \%$ in 2050, and $81 \%$ in 2080. Farmers adopting this adaptation strategy will have higher profits. Land value tends to be higher in both climate scenarios in counties with cultivated areas using transgenic seeds. Farmers adopting this adaptation measure will be less exposed to adverse effects of climate change. We conclude that it is necessary to invest in adaptation strategies so that Brazil can overcome adverse effects of global climate change.
\end{abstract}

Key-words: Climate change, adaptation, breeding, seeds, drought, heat.

Resumo: O melhoramento genético representa importante estratégia adaptativa para lidar com os efeitos das mudanças climáticas, principalmente mediante o desenvolvimento de sementes resistentes à seca ou elevadas temperaturas. Dessa forma, o presente trabalho apresenta uma análise de adaptação às mudanças climáticas enfatizando a adoção do

1. Thanks are due to CAPES (Coordenação de Aperfeiçoamento de Pessoal de Nível Superior), to FAPEMIG (Fundação de Amparo à Pesquisa do Estado de Minas Gerais), to CNPq (Conselho Nacional de Desenvolvimento Científico e Tecnológico) and to FUNARBE (Fundação Arthur Bernardes) for the scholarships and financial support; and to NEMESIS/IPEA (Núcleo de Estudos e Modelos Espaciais Sistêmicos) and specially Estáquio José Reis for the availability of climatic and agronomic databases. The authors are grateful to Marcia Pimentel and Juliana Speranza for the support in the database construction. Finally, we are grateful to anonymous referees for helpful comments and suggestions. All remaining errors are the authors.

2. Bolsista de Pós-doutorado (PNPD/CAPES) vinculado ao Programa de Pós-graduação em Economia Aplicada (PPGEA/UFV). E-mail: marcel.pires@ufv.br

3. Professor Adjunto do Departamento de Economia Rural da Universidade Federal de Viçosa. E-mail: denis.cunha@ufv.br 
melhoramento genético em fazendas brasileiras. O objetivo do trabalho foi investigar como as mudanças climáticas irão afetar a adoção do melhoramento genético e o lucro dos produtores. Foram utilizadas projeções de temperatura e precipitação para o período entre 2010-2099, considerando dois diferentes cenários climáticos (A1B e A2), de acordo com $04^{\circ}$ Relatório de Avaliação do IPCC (2007). Analiticamente, estimou-se um modelo de Efeito de Tratamento. Os resultados indicam que a probabilidade de utilizar sementes transgênicas irá aumentar de $74 \%$ no cenário atual para $86 \%$ em 2020, 83\% em 2050 e $81 \%$ em 2080. Os produtores que adotarem essa estratégia adaptativa apresentarão lucros maiores. Nas áreas onde o melhoramento genético é utilizado na agricultura, os valores da terra serão maiores em ambos os cenários climáticos. Os produtores adaptados estarão menos expostos às consequências negativas das mudanças climáticas. Nesse sentido, verifica-se a necessidade de investimento em estratégias de adaptação para que o Brasil possa superar os efeitos adversos das mudanças climáticas.

Palavras-chaves: Mudanças climáticas, adaptação, melhoramento genético, sementes, seca, calor.

JEL Classification: Q12, Q54.

\section{Introduction}

The agricultural sector is one of the most vulnerable to climate change because it directly depends on temperature and rainfall (DESCHÊNES and GREENSTONE, 2007). High temperatures and water deficit are commonly associated with reduced crop yields (SCHLENKER and ROBERTS, 2009; LOBELL et al., 2011), and predictions for future global warming have raised concerns regarding future yield and food security (BATTISTI and NAYLOR, 2009; BUTLER and HUYBERS, 2013). According to Nelson et al. (2013), the average effect of climate change on yields of different groups of crops and geographic regions is a $17 \%$ decline around the world. Effective adaptation of agriculture to climate change in the developing world will require information about the relative risks posed by climate change and the likely mechanisms of potential damage, to prioritize among different types of possible solution (LOBELL et al., 2011).

On a global scale, a growing recognition is given to the significant role that adaptation strategies play in determining the success of climate change policies. According to Seo and Mendelsohn (2008a), taking into account adaptation in order to adequately quantify the impacts of climate change on agriculture is mandatory nowadays. Those analyses cannot simply esti- mate how a particular crop will be affected, but it should recognize farmers will change their production decisions to maximize profit according to each climate scenario. Thus, studies that assume farmers will continue performing the same activities without changing their production techniques certainly overestimate losses.

Planning for climate adaptation necessarily requires comparisons of different alternatives, accounting for the possibilities and limitations of each technology as well as for the uncertainties associated with climate change (PIDGEON and FISCHHOFF, 2011). The main adaptation strategies in the agricultural sector include crop diversification and switching, changes in planting and harvesting seasons, adoption of irrigation practices, use of soil conservation techniques, shading and genetic breeding. Some recent works reported the significance of irrigation as an adaptive measure to climate change both in the South American (SEO, 2011) and Brazilian contexts (CUNHA et al., 2013; CUNHA et al., 2014) and others assessed the contribution of crop switching to farmers in South America (SEO and MENDELSOHN, 2008a, 2008b; SEO, 2010). However, the extent to which the genetic breeding can mitigate such temperature- and waterrelated losses remains unclear (ARAUS et al., 2008; BARNABAS et al., 2008). According to the Brazilian Panel on Climate Change (PBMC, 2013), 
more efforts considering agricultural scenarios that incorporate genetic improvement of crops (mainly drought-tolerant cultivars) are necessary.

The discovery of recombinant DNA technology allowed the development of genetically modified (GM) organism aiming to achieve, among other traits, increased tolerance or resistance to high temperature, drought, pathogens, and specific herbicide groups. Nowadays, both traditional breeding and genetic engineering of crop plants have been used to improve drought and heat resistance aiming at increasing agricultural productivity in regions affected by global warming (OH et al., 2011). Plant breeding also allows farmers to employ strategies for more rational use of soil and water, weed management, and general inputs that allow increased production and income (DA SILVA et al., 2007). According to the same authors, herbicide-resistant GM crops may be useful to employ broad-spectrum herbicides as well as to enable the use of less poisonous and readily biodegradable compounds, increasing the options to combat weeds (DA SILVA et al., 2007). In recent years, developments in non-GM DNA-based technologies have been applied to understanding the genetic control of important plant characteristics in crops. Such developments have provided several effective and new opportunities for the study of plant responses to the environment, including very complex traits such as drought and heat resistance.

To date, GM crops occupy $8.5 \%$ of $\sim 1.5$ billion hectares of all cropland in the world (JAMES, 2013). This report showed developing countries were the main responsible for this amount. Brazil, Argentina, China, India, and South Africa planted 83 million hectares of GM crops in 2013, equivalent to $47 \%$ of the global total area, and are driving the adoption of GM crops in developing countries. Moreover, transgenic soybean is the main transgenic crop, occupying 85 million hectares or $49 \%$ of global transgenic area, followed by maize ( 60 million hectares, or $34 \%)$, cotton (20 million hectares, or 11\%), and canola (10 million hectares, or 6\%). Thus, GM crops are already contributing to sustainability and can help mitigate the effects of climate change by contributing to food, feed and fiber security, and self-sufficiency, including more affordable food, and by increasing productivity and economic benefits to farmer sustainability (JAMES, 2013).

Several studies that analyzed climate change impacts on Brazilian agriculture (SIQUEIRA et al., 1994; SANGHI et al., 1997; EVENSON and ALVES, 1998; NOBRE et al., 2005; ÁVILA et al., 2006; EMBRAPA, 2008) are unanimous in stating climate change will cause a negative impact on the country. However, most of these studies did not consider adaptation, which may overestimate the impacts. The explicit inclusion of genetic breeding as an adaptive strategy provides better understanding of the impacts on the Brazilian agricultural sector, thus contributing more effectively to future public policies aimed at creating strategies to combat the effects of global warming on agriculture. Here we investigated how climate variability affects the adoption of genetic breeding and if this adaptation strategy will reduce the vulnerability of Brazilian agriculture to climate alterations. Following the studies of Mendelsohn et al. (1994), Seo (2011) and Cunha et al. (2014), our analysis considered Brazil as a whole and the aggregation of all crops cultivated in the country at the same estimation model.

\section{Methodology}

\subsection{Analytical framework}

This study tests the hypothesis that genetic breeding (specifically transgenic seeds) as an adaptive strategy tends to reduce the negative effects of global climate change on the Brazilian agricultural sector. In fact, this decision is commonly taken in a process to maximize benefits to ensure that only optimal choices are observed regardless of which option was selected. This choice is an optimization action influenced by the environment in which farmers dwell (personal characteristics, economic conditions etc.).Transgenic seed adoption is voluntary and may be based on 
individual self-selection. Therefore, this is a classic non-random treatment assignment. In this scenario, the traditional regression analysis may not capture the true effects of transgenic seeds on agricultural profits. This problem can be solved by matching methods, using a class of estimators called Propensity Score-Matching (PSM). This methodology was first suggested by Rosenbaum and Rubin (1983). In this study, the standard matching procedure described in Heckman and Robb (1986), Heckman et al. (1997, 1998) and Bento et al. (2007) was adopted.

According to Bento et al. (2007), let $Y_{1}$ be the potential outcome in the treated state, which is the land value of the county that adopted transgenic seeds, and $Y_{0}$ is the potential outcome that would have happened in non-adopted transgenic seeds counties. The farmer profitability was represented by land values because, according to Mendelsohn et al. (1994), they are simply the present value of profits (or net revenues). These are called potential outcomes because only one of $\left(Y_{0}, Y_{1}\right)$ is observed for each county. Let $D=1$ indicate a county with areas that use transgenic seeds and let $D=0$ indicate a county without such areas. Finally, let $X$ be a vector of observed covariates affecting both transgenic seeds adoption and outcomes. These covariates, such as soil, climatic characteristics and socioeconomic aspects of the counties will be detailed below.

The effect of transgenic seeds adoption on farm profitability (measured by land values) is the parameter of interest. It is calculated by the mean effect of being in a county with areas that use transgenic seeds versus an observationally equivalent county, as measured by $X$, that does not use transgenic seeds. Formally, the parameter of interest is:

$$
\Delta \mathrm{TT}=\mathrm{E}\left(\mathrm{Y}_{1}-\mathrm{Y}_{0} \mid \mathrm{D}=1\right)
$$

where $\Delta \mathrm{TT}$ refers to the average treatment effect on the treated observations.

The matching method consists of finding a proxy for $\mathrm{Y}_{0}$, since $\mathrm{Y}_{0}$ is not observed for this treated observation (e.g., $\mathrm{D}=1$ ) (BENTO et al., 2007). This proxy is called counterfactual outcome, e.g., the one that would have resulted in case an individual farmer had not used transgenic seeds. Propensity score estimator will be defined as an estimator for $E\left(Y_{0} \mid D=1\right)$, using an appropriate subset of the $\mathrm{D}=0$ data. Matching estimators pair each treated observation with one or more observationally similar non-treated observations, using the conditioning variables, $X$, to identify similarity. This methodology is justified if it can be argued that conditional on these $X^{\prime}$ s outcomes are independent of the selection process. Rosenbaum and Rubin (1983) demonstrated this independence condition holds conditional on the propensity score $\mathrm{P}(\mathrm{X})$ as well, which leads to the propensity score matching method.

The model estimation was carried out in three stages. First, a probit model of transgenic seed adoption was estimated. The probit equation representing the adoption is:

$$
Y_{i}^{*}=\alpha^{\prime} X_{i}+\mu
$$

where $Y_{i}^{*}$ is latent variable representing the transgenic seed adoption; $X_{i}$ is the vector of variables associated to the adoption; and $\mu$ is the error term $\left[E\left(\mu_{i}\right) \sim N(0,1)\right]$. The value of $Y_{i}$ actually observed is:

$$
Y_{i}=\left\{\begin{array}{lll}
1 & \text { if } \pi^{\mathrm{GM}}>\pi \\
0 & \text { if } \pi^{\mathrm{GM}}<\pi
\end{array}\right.
$$

where $\pi^{\mathrm{GM}}$ and $\pi$ indicates, respectively, the profits under adoption and non-adoption of transgenic seeds.

The probability of transgenic seed adoption, conditional to the values of the variables present in $X$ is given by:

$$
p\left(Y_{i}=1 \mid X_{i}\right)=G\left(\alpha_{0}+\alpha_{1} X_{1 i}+\ldots+\alpha_{k} X_{k i}\right)
$$

where $\mathrm{G}$ is the standard normal cumulative distribution function $\left[G(z)=\Phi(z)=\int_{-\infty}^{z} \phi(z) d z\right]$.

The values of $p\left(Y_{i}=1 \mid X_{i}\right)$ are strictly between 0 and 1 for all values of parameters, which is guaranteed by the choice of $G$. The estimated coefficients of the probit model were used to predict the probability of using transgenic 
seeds for each observation, e.g., the propensity score.

In the second stage, the data were divided into treatment (counties that used transgenic seeds) and control group (non-adopted transgenic seeds counties, but presented similar characteristics to those that adopted them), using the propensity scores. In the last step, it was estimated a counterfactual for each treated observation $\left(Y_{1} \mid \mathrm{D}=1, \mathrm{P}[\mathrm{X}]\right)$ based on $\left(\mathrm{Y}_{0} \mid \mathrm{D}=0, \mathrm{P}[\mathrm{X}]\right)$ the kernel matching. Average effect of treatment on the treated (conditional mean difference), e.g., the impact of use transgenic seeds on farmers who actually adopted them is:

$$
\begin{aligned}
\Delta \mathrm{TT} & =\left\{\mathrm{Y}_{1}-\mathrm{Y}_{0} \mid \mathrm{D}=1\right\} \\
& =\mathrm{E}\left[\mathrm{E}\left\{\mathrm{Y}_{1}-\mathrm{Y}_{0} \mid \mathrm{D}=1, \mathrm{P}[\mathrm{X}]\right\}\right] \\
& =\mathrm{E}\left[\begin{array}{l}
\mathrm{E}\left\{\mathrm{Y}_{1} \mid \mathrm{D}=1, \mathrm{P}[\mathrm{X}]\right\}- \\
-\mathrm{E}\left\{\mathrm{Y}_{0} \mid \mathrm{D}=0, \mathrm{P}[\mathrm{X}]\right\} \mid \mathrm{D}=1
\end{array}\right]
\end{aligned}
$$

As this research aimed to analyse the medium and long-term effects of climate change on agriculture, some time simulations were performed. Thus, projections of temperature and rainfall were used for three time periods: 2010-2039, 2040-2069 and 2070-2099. We considered two climate scenarios (A1B and A2), according to the Intergovernmental Panel on Climate Change (IPCC, 2007).

\subsection{Description of the data set}

Three variables categories (climatic, agronomic and socioeconomic) were used to compose the $X$ vector (Table 1 ). The observation unit of each variable was the Minimum Comparable Area (MCA), which refers to aggregated area of the smallest number of counties needed to ensure comparisons of same geographical area at different periods. Since MCAs represent municipality-level observations, we will refer to them as counties. The use of farm-level data for each variable would be ideal. However, our main data source (Instituto Brasileiro de Geografia e Estatística - IBGE) only provides these data without identifying geographic coordinates (latitude and longitude) to preserve the confidentiality of the farmers who answered to the Agricultural Census' questionnaires. Therefore, to assign values of climate variables to each farmer become impossible (CUNHA et al., 2014). Accordingly, the model was applied considering 3123 counties (instead of farmers) and the aggregation of all crops planted and harvested.

We cannot conclude exactly how many small, medium or large farmers have been included in the sample. It was known that average county har-

Table 1. Climatic, agronomic and socioeconomic variables used in this work

\begin{tabular}{ll}
\hline \multicolumn{1}{c}{ Variable } & \multicolumn{1}{c}{ Description } \\
\hline $\begin{array}{l}\text { Climatic variables } \\
\text { Summer temperature }\end{array}$ & $\begin{array}{l}\text { Summer average temperature }\left({ }^{\circ} \mathrm{C}\right) \\
\text { Summer rainfall }\end{array}$ \\
$\begin{array}{l}\text { Sinter temperature } \\
\text { Winter average temperature }\left({ }^{\circ} \mathrm{C}\right)\end{array}$ \\
$\begin{array}{l}\text { Winter rainfall } \\
\text { Temperature variability }\end{array}$ & Winter total rainfall $(\mathrm{mm})$ \\
Rainfall variability & Second moment of temperature distribution \\
\hline Agronomic variables & Second moment of rainfall distribution \\
Water resources & Number of agricultural establishments with water resources \\
High agricultural potential & Proportion of land area in the county with high soil quality \\
Low agricultural potential & Proportion of land area in the county with low soil quality \\
\hline Socioeconomic variables & \\
Farm income & Value of income earned by the farms $(1000$ R $\$)$ \\
Age of head & Number of farms run by someone from 25 to 45 years old \\
Education of head & Number of farms managed by someone graduated \\
Without technical guidance & Number of farms which has not any technical guidance \\
Seeds costs & Mean value of seed cost per county $(\mathrm{R} \$)$ \\
Land value & County land value $(1000$ R $\$)$ \\
\hline
\end{tabular}

Source: Research data. 
vested area with transgenic seeds was around 590 hectares, according to the Brazilian Agricultural Census. That was the Agricultural Census variable used to perform propensity score estimation. However, it was observed in our sample some counties in which average harvested area with transgenic seeds was less than 1 hectare. That is a strong evidence that even small farmers could be adopted this adaptive strategy in Brazil. Thus, we can consider that different classes of farmers were indirectly included in our study.

Socioeconomic variables and those related to access to water resources were obtained from the 2006 Agricultural Census, published by IBGE (Table 1). The agronomic aspects used referring to types of soil were provided by the Núcleo de Estudos e Modelos Espaciais Sistêmicos (NEMESIS/IPEA). These variables were created by overlaying geo-referenced county boundaries over geo-referenced land-attribute data. Andersen and Reis (2007) were responsible for the compatibility of the database used in this study (Table 1).

The observed temperature and rainfall data for each county was extracted from CL 2.0 10' dataset, produced by the Climate Research Unit CRU/University of East Anglia. The observed climate variables are temperature $\left({ }^{\circ} \mathrm{C}\right)$ and rainfall (mm/month), for the 1961-1990 period. Monthly values were averaged to create two seasonal means: December through February (summer) and June through August (winter). According to Féres et al. (2008), "this seasonal specification decreases information losses associated with the conventional use of one month from each season and, at the same time, maintains a measure of the trends in intra-annual variation". In order to construct those variables, all climate data were converted by NEMESIS/IPEA into arcGIS shapefiles using their $X Y$ coordinates, and these grid-points were joined to the county boundary layer. Finally, average temperature and rainfall were calculated for each county (FÉRES et al., 2008). The construction of climate variables database was performed by NEMESIS/IPEA. Unlike of some analysis already carried out for Brazil, which included only the first moments of temperature and rainfall distributions (SIQUEIRA et al., 1994; SANGHI et al., 1997; EVENSON and ALVES, 1998; NOBRE et al., 2005; ÁVILA et al., 2006; EMBRAPA, 2008), in our study climate variability was considered and the second moments of these distributions were included.

It is important to highlight the decision of considering only summer and winter temperature and rainfall instead of all four seasons. According to Seo and Mendelsohn (2008b) and Seo (2010, 2011), such specification is more appropriate to studies related to South America, since this region does not present four well defined seasons, as observed in the USA or Europe. However, several specifications that also included all seasons were tested. The estimated models, with variables related to summer, autumn, winter, and spring, presented few statistically significant coefficients (data not shown), confirming their low adequacy to the Brazilian case.

Following Oliveira et al. (2013) and Cunha et al. (2014) we used average data of 10 AtmosphericOceanic General Circulation Models (AOGCMs) to avoid individual model biases. According to these authors, an average of climate variables from different climate models is likely to be more representative than estimates of any individual model. The following AOGCMs were used: CNRM_cm3, CSIRO_MK3.0, GFDL CM2.1, GISS ER, IPSL_CM4, MIROC3.2_medres, MPI ECHAM5, MRI CGCM2.3.2, UKMO_HADCM3, and UKMO_HadGEM1.

The two emission scenarios adopted (A1B and A2) are based on the $4^{\text {th }}$ Assessment Report of IPCC (2007). For each model, climate data for four time series were provided: 1961-1990 (named current), 2010-2039 (2020), 2040-2069 (2050), and 2070-2099 (2080). Time series were used rather than single year projections in order to prevent selection of an outlier projection-year, and provide a better measure of overall trend (FÉRES et al., 2008). Data on projected climate change were provided by NEMESIS/IPEA. Table 2 summarizes the climate scenarios of our three models for three time periods. 
Table 2. Brazilian average AOGCM climate scenarios

\begin{tabular}{|c|c|c|c|c|c|c|c|c|c|c|c|c|c|c|}
\hline \multirow{3}{*}{ Variables } & \multicolumn{2}{|c|}{ Current Period } & \multicolumn{6}{|c|}{ A1BScenario } & \multicolumn{6}{|c|}{ A2Scenario } \\
\hline & \multirow[b]{2}{*}{ Treated } & \multirow[b]{2}{*}{ Control } & \multicolumn{3}{|c|}{ Treated } & \multicolumn{3}{|c|}{ Control } & \multicolumn{3}{|c|}{ Treated } & \multicolumn{3}{|c|}{ Control } \\
\hline & & & $\begin{array}{c}2010- \\
2039 \\
\end{array}$ & $\begin{array}{c}2040- \\
2069 \\
\end{array}$ & $\begin{array}{c}2070- \\
2099 \\
\end{array}$ & $\begin{array}{c}2010- \\
2039 \\
\end{array}$ & $\begin{array}{c}2040- \\
2069 \\
\end{array}$ & $\begin{array}{c}2070- \\
2099 \\
\end{array}$ & $\begin{array}{c}2010- \\
2039 \\
\end{array}$ & $\begin{array}{c}2040- \\
2069 \\
\end{array}$ & $\begin{array}{c}2070- \\
2099 \\
\end{array}$ & $\begin{array}{c}2010- \\
2039 \\
\end{array}$ & $\begin{array}{c}2040- \\
2069 \\
\end{array}$ & $\begin{array}{c}2070- \\
2099 \\
\end{array}$ \\
\hline Summer temperature & 24.65 & 24.20 & 25.70 & 26.69 & 27.68 & 25.02 & 25.99 & 27.03 & 25.66 & 26.69 & 28.17 & 24.99 & 26.03 & 27.52 \\
\hline Summer rainfall & 158.41 & 190.44 & 153.32 & 156.46 & 158.98 & 182.93 & 185.93 & 185.04 & 154.87 & 156.52 & 158.75 & 182.67 & 183.13 & 185.49 \\
\hline Winter temperature & 20.48 & 19.59 & 22.00 & 22.99 & 23.94 & 20.98 & 21.99 & 22.98 & 21.92 & 22.87 & 24.44 & 20.87 & 21.85 & 23.47 \\
\hline Winter rainfall & 56.10 & 51.28 & 63.24 & 63.00 & 68.80 & 62.16 & 62.37 & 62.48 & 62.89 & 62.63 & 62.74 & 61.77 & 62.20 & 62.63 \\
\hline
\end{tabular}

Notes: 1) A1B and A2 refer to the Intergovernmental Panel on Climate Change scenarios (IPCC, 2007); 2) Current refers to the baseline climate for 1961-1990.

Source: Climate Research Unit - CRU/University of East Anglia; Núcleo de Estudos e Modelos Espaciais Sistêmicos (NEMESIS/IPEA).

Finally, the dependent variable of Treatment Effect Model is land value. This variable is measured in terms of monetary units (1000 R\$) and it is provided by the IBGE 2006 Agricultural Censuses. Land values represent the best estimations by farmers of the value of their land without any improvements, such as buildings. Following Schlenker et al. (2005), we have omitted all urban counties because the strong influence of urbanization on farmland values could cause bias. All statistical procedures were performed using the Stata 12.0 software system (Stata Corp LP, College Station, TX, USA).

\section{Results and discussion}

Among 3123 counties considered in this work, 2039 ( $\sim 65 \%$ of total sample) presented areas where transgenic seeds were adopted. It was observed that counties using transgenic seeds were exposed to higher temperatures in both summer and winter seasons. On the other hand, those counties were exposed to a lower volume of rainfall during summer. Both productions are also exposed to high rainfall and low temperature variability (Table 3$)^{4}$. These results are in agreement with adoption of adaptive strategies, as evidence of use of heat or drought resistant seeds.

4. Values of temperature and rainfall (summer and winter) presented in Table 3 are related to average of 30 years considering aggregated data of all Brazilian regions.
Drought is a pivotal environmental factor limiting the productivity of crops worldwide. Climate change models predict greater variability in rainfall patterns, and increased periods of summer drought will affect many regions, including temperate grasslands. Furthermore, raising temperature is expected to cause severe water deficit in crop plants and, eventually, food shortages. The irregular rainfall patterns lead to seasonal soil water deficit and decreased productivity. Population growth will also require more of the available water to be used for domestic and industrial use, rather than for irrigating crops, giving a double benefit for productive crops exhibiting enhanced drought resistance and water use efficiency. Climate changes may also lead to increased incidence of pathogens, such as diseases caused by Fusarium, which are more severe in dry environments (BOOTH, 1971; SCHAAFSMA and HOOKER, 2007). Changes in temperature and rainfall patterns may affect the susceptibility of plants to pathogens. Plants growing in optimal temperature, water and nutrient conditions are able to tolerate a certain degree of infection. However, in less favorable environmental conditions, such as those resulting from climate change, plants become less tolerant and more susceptible to pathogen infection (ROBERT et al., 2000; CHAKRABORTY and NEWTON, 2011; PAUTASSO et al., 2012). Thus, the use of GM crops resistant or tolerant to drought and pathogens becomes an essential tool for increasing productivity, especially in regions where climate 
Table 3. Descriptive statistic on agricultural production in Brazil

\begin{tabular}{lcccc}
\hline \multicolumn{1}{c}{ Variable } & \multicolumn{2}{c}{ Treated } & \multicolumn{2}{c}{ Control } \\
\cline { 2 - 5 } & Mean & Std & Mean & 1.96 \\
\hline Summer temperature & 24.64 & 1.97 & 24.19 & 68.47 \\
Summer rainfall & 158.41 & 74.80 & 190.44 & 3.43 \\
Winter temperature & 20.48 & 4.00 & 19.59 & 50.51 \\
Winter rainfall & 56.09 & 52.10 & 51.28 & 2.12 \\
Temperature variability & 3.71 & 3.19 & 3.80 & $3,209.85$ \\
Rainfall variability & $5,361.03$ & $3,792.87$ & $5,649.12$ & 125.05 \\
Water resources & 224.93 & 270.41 & 81.91 & 0.22 \\
High agricultural potential & 0.13 & 0.27 & 0.07 & 0.43 \\
Low agricultural potential & 0.52 & 0.41 & 0.64 & $28,151.00$ \\
Farm income & $10,425.38$ & $31,087.42$ & $11,276.70$ & 209.08 \\
Age of head & 425.01 & 428.77 & 31.12 & 32.91 \\
Education of head & 29.11 & 37.29 & 39.72 & 85.78 \\
Without technical guidance & 17.88 & 42.43 & 335.94 & $6,842.60$ \\
Seed costs & 278.31 & $1,056.13$ & $44,516.75$ & $83,516.48$ \\
Land value (R\$ 1000) & $56,531.79$ & $113,714.10$ & 1084 & - \\
Number of counties & 2039 & - & & \\
\hline
\end{tabular}

Note: Treated refers to counties with cultivated areas using transgenic seeds and Control refers to counties without areas using transgenic seeds. Source: Research data.

variability is characterized by low rainfall and high temperatures (BARIANA et al., 2007; ELLIS et al., 2007).

Some intriguing differences can be observed in agronomic and socioeconomic characteristics (Table 3). First, counties with croplands using transgenic seeds had more access to water and soil with high quality. These data indicate the use of transgenic seeds is related to agronomic conditions of croplands, because it would not be economically viable to adopt this strategy in areas where conditions were not satisfactory. Second, average of counties where there are farms that did not receive technical guidance was lower among those using transgenic seeds; these counties also had farmers with more experience than those not using transgenic seeds. On the other hand, access to higher education did not present significant differences. In general, counties with these characteristics are expected to have farmers with good knowledge about genetic breeding technology and therefore are more likely to adopt the strategy. Finally, average land values of counties that use transgenic seeds were higher than those of counties that have not adopted this strategy. This is the first evidence that use of transgenic seeds to reduce the risk associated to climate variability generates higher income to farmers and is an effective adaptation strategy.

Following the proposed methodological framework, the first part of the analysis consisted of estimating a probit model in order to obtain the propensity score (Table 4). The dependent variable received value 1 if there were areas using transgenic seeds in a given county and 0 , otherwise. All explanatory variables included were described in Table 1 . The model was highly significant according to the Likelihood ratio statistics. The parameters are mostly significant at $1 \%$ and $10 \%$ level, and all climate coefficients are statistically different from zero.

The estimated probit model indicates agronomic, socioeconomic, and climate conditions affect the use of transgenic seeds in Brazilian counties. Accesses to water resources and availability of land in good conditions for agricultural practice (in terms of soil quality) are important aspects. Moreover, adoption decision is also conditioned by technical expertise and management capacity of farmers, which involves the understanding of potentials and limitations, as well as operation and functioning of such technique. It 
Table 4. Probit estimateof transgenic seed adoption in Brazil

\begin{tabular}{lcc}
\hline \multicolumn{1}{c}{ Variable } & Estimate & $P$-value \\
\hline Summer temperature & $0.3249874^{* * *}$ & 0.0000 \\
Summer rainfall & $-0.0055190^{* * *}$ & 0.0000 \\
Winter temperature & $0.2428232^{* * *}$ & 0.0000 \\
Winter rainfall & $-0.0041580^{* * *}$ & 0.0000 \\
Temperature variability & $0.2162869^{* * *}$ & 0.0000 \\
Rainfall variability & $0.0000425^{* * *}$ & 0.0020 \\
Water resources & $0.0014623^{* * *}$ & 0.0030 \\
High agricultural potential & $0.2011681^{*}$ & 0.0760 \\
Low agricultural potential & $-0.1367245^{*}$ & 0.0500 \\
Farm income & $0.0000015^{*}$ & 0.0870 \\
Age of head & $0.0010751^{* * *}$ & 0.0000 \\
Education of head & $-0.0006022^{\mathrm{NS}}$ & 0.4790 \\
Without technical guidance & $0.0008311^{\mathrm{NS}}$ & 0.4270 \\
Seed costs & $-0.0000037^{\mathrm{NS}}$ & 0.3910 \\
Intercept & $3.160977^{* * *}$ & 0.0000 \\
\hline
\end{tabular}

Notes: 1) The Likelihood ratio statistics for the model is $1,677.69$ with $P<0.00001 ; 2) P$-Value ${ }^{\mathrm{HC}}$ denotes heteroscedasticity consistent $P$ values; 3$) *$ indicates significance at $10 \%$ and $* * *$ indicates significance at $1 \%$ of probability; 4) ${ }^{\mathrm{NS}}$ refers to no significant difference.

Source: Research data.

was also observed transgenic seeds have been adopted as a response to temperature changes rather than decreased rainfall. Those results allowed confirming the hypothesis that adoption of transgenic seeds is influenced by climate variations and, thus, can effectively be modeled as an adaptive strategy.

After propensity score estimation, it was possible to evaluate the performance of both counties that use and do not use transgenic seeds in current and future climate change scenarios proposed by IPCC (2007). This analysis was performed by calculating the average effect of treatment on the treated $(\Delta T T)$, for which the variable of interest was land value. Possible benefits of transgenic seeds as adaptive measure were evaluated as well as losses related to decision of not using these seeds. Figure 1 shows mean estimates of land value for each period of time and climate scenario.

Simulations were performed by changing the climatic conditions and maintaining socioeconomic and agronomic conditions unchanged (MENDELSOHN et al., 1994; SEO, 2011; CUNHA et al., 2014). It is worth highlighting that many aspects other than climate will change in the future, e.g., technological features, economic development, agricultural policy, international trade, etc. However, Seo (2011) explains that this kind of simulation aims to separate the effects of climate from other changes in economic conditions.

Results on Figure 1 show returns associated to use of transgenic seeds are always higher than the non-adopted systems in future simulations. Differences between two groups of counties are statistically significant at less than $1 \%$. Land values of counties where transgenic seeds are used tend to increase (although it was observed slight reduction in the period 2070-2099 in comparison to 2040-2069, in A1B scenario). Moreover, there is a significant reduction in land value of counties where agricultural production is performed exclusively without transgenic seeds. More specifically, losses can range from $\mathrm{R} \$ 21.7$ million (scenario A1B) in a short term to $\mathrm{R} \$ 15.8$ million (scenario A2) in a long term 5 .

5. The results that support this discussion are in the Appendix (Table A1). To explore the sensitivity of estimates to unobserved variables, as well as to confirm robustness of our model, we performed the test of Rosenbaum limits. The result (Table A2) showed there is nonsignificant bias arising from omitted variables in our model. 
Figure 1. Impact of climate scenarios on conditional land value of treated and non-treated Brazilian farmers.
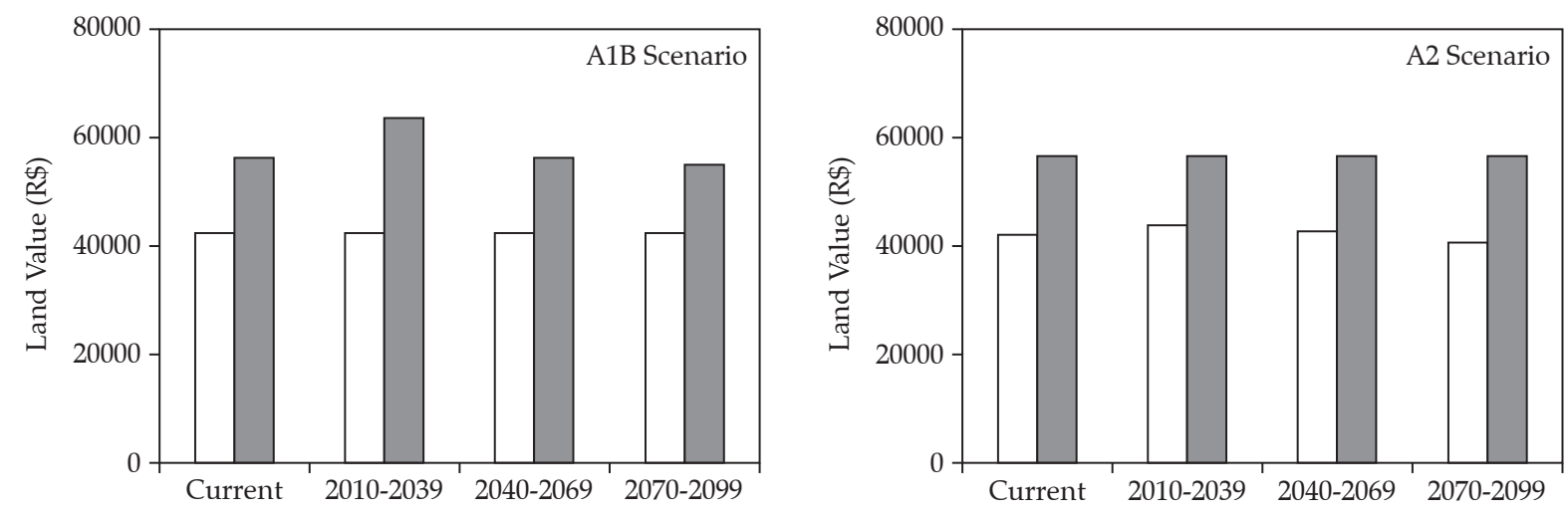

Notes: 1) Treated refers to counties with cultivated areas using transgenic seeds and Control refers to counties without areas using transgenic seeds; 2) Land values are represented in $\mathrm{R} \$ 1000$.

Source: Research data.

According to Schlenker et al. (2005), benefits and costs are capitalized in future land values. Thus, profits achieved with transgenic seed adoption outweigh its costs under climate change scenarios. This result is consistent with those presented by Margulis and Dubeux (2010). According to these authors, the relationship between cost of investment in genetic breeding and benefit (measured by losses avoided) seems to be advantageous, ranging from $8 \%$ in 2020 to $5 \%$ in 2070 for soybean production, and $8 \%$ to $11 \%$ for rice production.

The prior expectations that adoption of genetic breeding could be used as an adaptive strategy to cope climate variations was confirmed by our results. Our results suggested counties where there are areas cultivated using transgenic seeds will be less exposed to negative effects of climate change. Average global temperatures have been continuously growing since the past decades and will continue to increase in coming years, which may present high frequency of extremely hot days (ASSENG et al., 2011). Temperature rise is expected to accelerate phenological processes of plant development, resulting in a short growing season. A wide range of crops are vulnerable to thermal stress. Wheat plants exposed to high temperature, for example, show rapid leaf senescence and reduction of about $50 \%$ of grain yield (ZHAO et al., 2007). Furthermore, interactions between the predicted increase in air temperature (and, consequently, in soil temperature), dormancy and seed viability could lead to decreased agricultural productivity, especially in developing countries located at lower latitudes. According to our results, by using transgenic seeds tolerant or resistant to high temperature, Brazilian counties will decrease risks related to changes in weather pattern, avoiding direct and indirect losses.

According to FAO (2003) and Gornall et al. (2010), changes in water availability are another important consideration. Water deficit limits growth and development of plants and this problem tends to worsen in climate change scenarios. About $70 \%$ of water in our planet is used for agricultural purposes; it is estimated that about 3000 liters of water are necessary to feed one person per day. Water use has increased substantially with agricultural productivity improvement, which can lead to depletion of surface and underground water. Drought resulting from climate change can lead to sharp increases in food prices and poverty in developing countries. This trend should persist because of changes in weather patterns resulting from climate change (FAO, 2003; GORNALL et al., 2010). The use of GM crops less vulnerable to drought, obtained 
from a group of genes that collectively optimize water use, is an economically viable alternative to overcome predicted impacts of climate change. Thus, addressing temperature and water issues requires most realistic estimates that are possible of plant response to climate change.

Sensitivity to heat is clearly increased in extreme drought situations, with even the coolest sites hurt by warming in absence of adequate soil moisture. Thus, agronomic measures to improve soil moisture and genetic breeding efforts to produce drought-tolerant crops are not only beneficial for managing present and future risks of drought, but are also probably important strategies to deal with future global warming. Conversely, improvements in heat tolerance may also limit losses during drought conditions (BATTISTI and NAYLOR, 2009).

However, there are still legal and cultural barriers against use of transgenic seeds in Brazil. Much has been said about the dangers to environment and human health related to GM crops. Nowadays, there are few transgenic lines approved and commercially available in Brazil. Regardless of political and speculative issues, this study aimed to simply analyse the cost and benefit of use of transgenic seeds in a perspective of global climate change. It is known that transgenic seeds adoption involves several reductions in production costs, such as demands for water, pesticides and herbicides. Furthermore, GM crops have increased their productivity, since annual yields are higher. Thus, it is believed legal and cultural restrictions on GM crops adoption will be relieved in coming years, given the upcoming effects of climate change.

Our results are regarding to Brazil as a whole and constitute a first attempt to understand the role of genetic breeding as an adaptive measure. Consequently, different regions and biomes may have different answers according to their specificities. In this sense, Brazilian public authorities need to consider regional differences when developing policies for adaptation to climate because their effects will not be identical throughout the country. At the same time, we need to reflect about the weight of this strategy in comparison to other agricultural practices. Margulis and Dubeux (2010) reported genetic breeding is more cost effective than irrigation for rice and bean. On the other hand, some adaptive measures such as changes in planting and harvesting seasons or shading may be less expensive. However, the Brazilian Panel on Climate Change (PBMC, 2013) advised that as climate conditions become more severe, the adoption of new cultivars adapted to new weather patterns become of pivotal importance. Then reinforces that GM adoption must be combined with alternative agricultural techniques such as no-till farming or integrated production systems in order to ensure increased crop yield and food security.

\section{Conclusions}

The results presented in this study confirmed prior expectations that adoption of genetic breeding is influenced by climate variations and should be modeled as an adaptive strategy. The main contribution of this work was to provide estimates of impacts of climate change in different future scenarios as well as modeling adaptation in an endogenous way to the model.

Probit estimates analysis revealed that transgenic seeds have been adopted as a response to temperature variations rather than to reduced rainfall under current conditions. This trend suggests variations in precipitation are less important for adoption of transgenic seeds in Brazil than temperature, but probably also results from a strong covariance between temperature and precipitation that makes inclusion of the latter partially redundant.

Altogether the results that were found in this work clearly demonstrated the average land values of counties with cultivated areas using transgenic seeds tend to be more stable, demonstrating their effectiveness as an adaptive measure. In addition, it provided novel insights into the role of GM crops to improve agricultural performance of the country, making Brazil less vulnerable to 
climate change. It is confirmed, thus, the need to include adaptation measures in estimation, providing good assessment of the actual events. Ignoring the adjustment makes the estimation of impacts overestimate damages, sometimes dramatically. Losses to Brazilian agricultural yield from increased temperature and water deficit are almost certainly overestimated if adaptation is not accounted for. Here we have shown that genetic breeding could decrease average fractional losses. Nevertheless, our results should not lead to an inappropriate conclusion that all Brazilian cultivars should be transgenic. We have only demonstrated GM adoption as an alternative, among other adaptive strategies, which can be succeed in future climate change scenarios.

However, it is necessary to point out some limitations of this study. Our work did not capture the full range of adjustments that can be performed; in particular, when assuming fixed portions of land, it was not possible to consider how the pattern of land use for (non) agricultural purposes will change. Since it is a partial equilibrium study, it does not deal with implications of these results in terms of effects on other sectors of economy. The results presented here suggest that further analysis should consider these issues.

It is also important to note that studies of crosstalk simulations of different adaptive measures, such as an integrative view of the relations between irrigation and genetic breeding, must be of great value to understand the magnitude of impacts. Furthermore, there are also potential benefits to warming that we have not included in our model, such as greater flexibility in planting times, a longer growing season and opportunities for cultivating new regions. Finally, more efforts are needed to clarify the overall significance of regional impacts of climate change in different biomes and crops grown in Brazil, particularly in scenarios of increased temperature and decreased rainfall patterns.

Although our results indicate a less pessimistic scenario for effects of climate change, public policies such as national breeding programmes should seek strategies to combat the effects of global warming in agriculture sector. Given the importance of genetic breeding to mitigate effects of climate change, specific credit policies for future research in this area should be encouraged. Moreover, the prospect that adaptation strategies could have such a significant influence on future yields provides impetus for further study.

\section{References}

ARAUS, J. L., SLAFER, G., ROYO, C. and SERRET, M. D. Breeding for yield potential and stress adaptation in cereals. Critical Review in Plant Sciences, v. 27, p. 377412, 2008.

ASSENG, S., FOSTER, I. and TURNER, N. C. The impact of temperature variability on wheat yields. Global Change Biology, v. 17, p. 997-1012, 2011.

ÁVILA, A.F.D., IRIAS, L.J.M. and LIMA, M. Impacto das mudanças climáticas na agricultura brasileira. Brasília: EMBRAPA, 2006.

BARIANA, H.S., BROWN, G.N., BANSAL, U.K., MIAH, H., STANDEN, G.E. and LU, M. Breeding triple rust resistant wheatcultivarsforAustraliausing conventional and marker-assisted selectiontechnologies. Australian Journal of Agricultural Research, v. 58, p. 576-587, 2007.

BARNABAS, B.A.T., JAGER, K. and FEHER, A. The effect of drought and heat stress on reproductive processes in cereals. Plant, Cell and Environment, v. 31, p. 11-38, 2008.

BATTISTI, D.S. and NAYLOR, R.L. Historical warnings of future food insecurity with unprecedented seasonal heat. Science, v. 323, p. 240-244, 2009.

BENTO, A., TOWE, C. and GEOGHEGAN, J. The effects of moratoria on residential development: evidence from a matching approach. The American Journal of Agricultural Economics, v. 89, p. 1211-1218. 2007.

BООТН, K.J. The Genus Fusarium. London: Commonwealth Mycological Institute, 1971.

BUTLER, E.E. and HUYBERS, P. Adaptation of US maize to temperature variations. Nature Climate Change, v. 3, p. 68-72, 2013.

CHAKRABORTY, S. and NEWTON, A.C. Climate change, plant diseases and food security: anoverview. Plant Pathology, v. 60, p. 2-14, 2011.

CHAVES, M.M., PEREIRA, J.S., MAROCO, J., RODRIGUES, M.L., RICARDO, C.P.P., OSORIO, 
M.L., CARVALHO, I., FARIA, T. and PINHEIRO, C. How plants cope with water stress in the field? Photosynthesis and growth. Annals of Botany, v. 89, p. 907-916, 2002.

CUNHA, D.A., COELHO, A.B. and FÉRES, J.G. Irrigation as an adaptive strategy to climate change: an economic perspective on Brazilian agriculture. Environment and Development Economics, DOI: http:// dx.doi.org/10.1017/S1355770X14000102.

, COELHO, A. B., FÉRES, J. G., BRAGA, M. J. and SOUZA, E. C. Irrigação como estratégia de adaptação de pequenos agricultores às mudanças climáticas: aspectos econômicos. Revista de Economia e Sociologia Rural, v. 51, n. 4, p. 369-386, 2013.

DA SILVA, M.P., VILLELA, F.A., DODE, L.B., MAGALHÃES, A.M. and TILLMANN, M.A.A. Identification of mutant rice seeds tolerant to imazethapyr herbicide. Revista Brasileira de Sementes, v. 29, p. 130-137, 2007.

DESCHÊNES, O. and GREENSTONE, M. The economic impacts of climate change: evidence from agricultural output and random fluctuations in weather. The American Economic Review, v. 97, p. 354-385, 2007.

ELLIS, J.G., MAGO, R., KOTA, R., DODDS, P.N., MCFADDEN, H., LAWRENCE, G., SPIELMEYER, W. and LAGUDAH, E. Wheat rust resistance research at CSIRO. Australian Journal of Agricultural Research, v. 56, p. 507-511, 2007.

EMPRESA BRASILEIRA DE PESQUISA AGROPECUÁRIA - EMBRAPA. Aquecimento Global e a nova Geografia da Produção agrícola no Brasil. 2008. Available at: <http:/www.embrapa.br/publicacoes/ tecnico/aquecimentoglobal.pdf $>$. Accessed: October 2012.

EVENSON, R.E. and ALVES, D.C.O. Technology, climate change, productivity and land use in Brazilian agriculture. Planejamento e Políticas Públicas, v. 18, p. 223-258, 1998.

FÉRES, J., REIS, E. and SPERANZA, J. Assessing the Impact of Climate Change on the Brazilian Agricultural Sector. In: $16^{\text {th }}$ Annual EAERE Conference, 2008, Gothenburg. Proceedings of the 16th Annual EAERE Conference. Gothenburg: EAERE, 2008.

FOOD AND AGRICULTURE ORGANIZATION OF THE UNITED NATIONS - FAO. The state of food insecurity in the world. 2003. Available at: <http://www. fao.org/publications/sofi/en/>. Accessed: January 2013.

GORNALL, J., BETTS, R., BURKE, E., CLARK, R., CAMP, J., WILLETT, K. and WILTSHIRE, A. Implications of climate change for agricultural productivity in the early twenty-first century. Philosophical Transactions of the Royal Society B: Biological Sciences, v. 365, p. 2973-2989, 2000.

HECKMAN, J. J. and ROBB, R. Alternative method for solving the problem of selection bias in evaluating the impact of treatments on outcomes. In: WAINER, H. (Ed.).Drawing Inferences from Self-Selected Samples. Berlin: Springer-Verlag, 1986. p. 63-107.

., ICHIMURA, H. and TODD, P.E. Matching as an econometric evaluation estimator: evidence from evaluating a job training programme. The Review of Economic Studies, v. 64, p. 605-654, 1997.

., ICHIMURA, H., SMITH, J.A. and TODD, P.E. Characterizing selection bias using experimental data. Econometrica, v. 66, p. 1017-1098, 1998.

INTERNATIONAL PANEL ON CLIMATE CHANGE - IPCC. Climate Change 2007: Synthesis Report. Contribution of Working Groups I, II and III to the Fourth Assessment Report of the Intergovernmental Panel on Climate Change. PACHAURI, R. K. and REISINGER, A. (Eds.). Geneva, Switzerland: IPCC, 2007.

JAMES, C. Global status of commercialized biotech/GM crops: 2013. International Service for the Acquisition of Agri-Biotech Applications (ISAAA) Brief Executive Summary 46. 2013. Available at: < http://www.isaaa.org/ resources/publications/briefs/46/executivesummary/ default.asp >. Accessed: January 2013.

LOBELL, D.B. and ASNER, G.P. Climate and management contributions to recent trends inUS agricultural yields. Science, v. 299, p. 1032-1032, 2003.

., BÄNZIGER, M., MAGOROKOSHO, C. and VIVEK, B. Nonlinear heat effects on African maize as evidenced by historical yield trials. Nature Climate Change, v. 1, p. 42-45, 2011.

MARGULIS, S. and DUBEUX, C.B.S. Economics of climate change in Brazil: costs and opportunities. São Paulo: USP, 2010.

MENDELSOHN, R., NORDHAUS, W. and SHAW, D. The Impact of Global Warming on Agriculture: Ricardian analysis. The American Economic Review, v. 84, p. 753-771, 1994.

NELSON, G. et al. Climate change effects on agriculture: economic responses to biophysical shocks. PNAS. Early Edition. (2013). DOI: 10.1073/pnas.1222465110.

NOBRE, C.A., ASSAD, E.D. and OYAMA, M.D.O impacto do aquecimento global nos ecossistemas 
brasileiros e na agricultura. Scientific American Brazil, v. 80, p. 70-75, 2005.

OH, J.E., KWON, Y., KIM, J.H., NOH, H., HONG, S-W. and LEE, H. A dual role for MYB60 in stomatal regulation and root growth of Arabidopsis thaliana under drought stress. Plant Molecular Biology, v. 77, p. 91-103, 2011.

OLIVEIRA, L.J.C., COSTA, M.H., SOARES-FILHO, B.S. and COE, M.T. Large-scaleexpansion of agriculture in Amazonia may be a no-win scenario. Environmental Research Letters, v. 8, p. 1-10, 2013.

PAINEL BRASILEIRO DE MUDANÇAS CLIMÁTICAS - PBMC. Contribuição do Grupo de Trabalho 2 ao Primeiro Relatório de Avaliação Nacional do Painel Brasileiro de Mudanças Climáticas. PBMC: Rio de Janeiro. 2013.

PAUTASSO, M., DÖRING, T.F., GARBELOTTO, M., PELLIS, L. and JEGER, M.J. Impacts of climate change on plant diseases - opinion sand trends. European Journal of Plant Pathology, v. 133, p. 295-313, 2012.

PIDGEON, N. and FISCHHOFF, B. The role of social and decision sciences in communicating uncertain climate risks. Nature Climate Change, v. 1, n. 1, p. 35-41, 2011.

PORTER J. R. Rising temperatures are likely to reduce crop yield. Nature, v. 436, p. 174, 2005.

ROBERT, Y., WOODFORD, J.A.T. and DUCRAYBOURDIN, D.G. Some epidemiological approaches to the control of aphid-borne virus diseases in seed potato crops in northern Europe. Virus Research, v. 71, p. 33-47, 2000.

ROSENBAUM, P.R. and RUBIN, D.B. The central role of the propensity score in observational studies for causal effects. Biometrika, v. 70, p. 41-55, 1983.

SANGHI, A., ALVES, D., EVENSON, R. and MENDELSOHN, R. Global warming impacts on Brazilian agriculture: estimates of the Ricardian model. Economia Aplicada, v. 1, p. 7-33, 1997.

SCHAAFSMA, A.W. and HOOKER, D.C. Climatic models to predict occurrence of Fusarium toxins in wheat and maize. International Journal of Food Microbiology, v. 119, p. 116-125, 2007.

SCHLENKER, W., HANEMANN, W.M. and FISHER, A.C. Will U.S. agriculture really benefit from global warming? Accounting for irrigation in the hedonic approach. The American Economic Review, v. 95, p. 395-406, 2005.

SCHLENKER, W. and ROBERTS, M.J. Nonlinear temperature effects indicate severe damage to U.S. crop yields under climate change. Proceedings of the National Academy of Sciences USA, v. 106, p. 15594-15598, 2009.

SEO N. and MENDELSOHN, R. An analysis of crop choice: adapting to climate change in South American farms. Ecological Economics, v. 67, p. 109-116, 2008a.

. and MENDELSOHN, R. A Ricardian analysis of the impact of climate change on South American farms. Chilean Journal of Agricultural Research, v. 68, p. $69-79,2008 b$.

A microeconometric analysis of adapting portfolios to climate change: adoption of agricultural systems in Latin America. Applied Economic Perspectives and Policy, v. 32, p. 489-514, 2010.

. An analysis of public adaptation to climate change using agricultural water schemes in South America. Ecological Economics, v. 70, p. 825-834, 2011.

SIQUEIRA, O.J.F., FARIAS, J.R.B. and SANS L.M.A. Potential effects of global climate change in Brazilian agriculture and adaptation studies for wheat, corn and soybeans. Revista Brasileira de Agrometeorologia, v. 2, p. 115-129, 1994.

THUILLER, W., LAVOREL, S., ARAUJO, M.B., SYKES, M.T. and PRENTICE I.C. Climate change threats to plant diversity in Europe. Proceedings of the National Academy of Sciences of the United States of America, v. 102, p. 8245-8250, 2005.

ZHAO, H., DAI, T.B., JING, Q., JIANG, D. and CAO, W.X. Leaf senescence and grain filling affected by postanthesis high temperatures in two different wheat cultivars. Plant Growth Regulation, v. 51, p. 149-158, 2007. 


\section{Appendix}

Table 1A. Impact of climate scenarios on conditional land value of treated and non-treated Brazilian farmers

\begin{tabular}{lcccc}
\hline \multicolumn{1}{c}{ Variable } & Treated & Control & $\Delta$ TT & $P$-value \\
\hline Land value (current period) & $56,134.57$ & $42,134.19$ & $14,000.37$ & 0.001 \\
\hline A1B Scenario & & & & \\
Land value (2010-2039) & $63,303.41$ & $41,570.25$ & $21,733.15$ & 0.000 \\
Land value (2040-2069) & $56,184.08$ & $42,045.39$ & $14,138.68$ & 0.000 \\
Land value (2070-2099) & $55,121.21$ & $40,635.91$ & $14,485.29$ & 0.000 \\
\hline A2 Scenario & & & & \\
Land value (2010-2039) & $56,607.35$ & $43,864.05$ & $12,743.29$ & 0.006 \\
Land value (2040-2069) & $56,348.82$ & $43,068.50$ & $13,280.32$ & 0.000 \\
Land value (2070-2099) & $56,531.78$ & $40,736.71$ & $15,795.07$ & 0.001 \\
\hline
\end{tabular}

Notes: 1) Treated refers to counties with cultivated areas using transgenic seeds and Control refers to counties without areas using transgenic seeds; 2) Land values are represented in $R \$ 1000$; 3) $\Delta T T$ was estimated by kernel matching; 4 ) $P$-values based on the standard error were calculated by bootstrap.

Source: Research data.

Table 2A. Test of Rosenbaum limits

\begin{tabular}{ccc}
\hline Variable & $\Gamma$ & P-value \\
\hline & 1.0 & 0.0000 \\
Land Values & 1.1 & 0.0000 \\
& 1.2 & 0.0000 \\
& 1.3 & 0.0000 \\
& 1.4 & 0.0000 \\
& 1.5 & 0.0000 \\
\hline
\end{tabular}

Source: Research data. 
